\title{
Resilience of the British and Irish seabird community in the twentieth century
}

\author{
Marine Grandgeorge ${ }^{1,2}$, Sarah Wanless ${ }^{3}$, Timothy E. Dunn ${ }^{4}$, Myriam Maumy $^{5}$, \\ Grégory Beaugrand ${ }^{6}$, David Grémillet ${ }^{1,7, *}$
}

${ }^{1}$ Centre National de la Recherche Scientifique, Centre d'Ecologie Fonctionnelle et Evolutive, 1919 route de Mende, 34293 Montpellier, France

${ }^{2}$ Centre National de la Recherche Scientifique, Laboratoire EthoS, Campus de Beaulieu, Bat 25, 263 avenue du Général Leclerc, 35042 Rennes, France

${ }^{3}$ Centre for Ecology and Hydrology, Bush Estate, Penicuik, Midlothian EH26 0QB, UK

${ }^{4}$ Joint Nature Conservation Committee, Dunnet House, 7 Thistle Place, Aberdeen AB10 1UZ, UK

${ }^{5}$ Laboratoire de Statistique, Université Louis Pasteur, 7 rue Descartes, 67084 Strasbourg, France

${ }^{6}$ Centre National de la Recherche Scientifique, Laboratoire d'Océanologie et de Géosciences, UMR LOG CNRS 8187, Station Marine, Université des Sciences et Technologies de Lille, 59000 Lille, France

${ }^{7}$ DST/NRF Centre of Excellence at the Percy FitzPatrick Institute of African Ornithology, University of Cape Town, Rondebosch 7701, South Africa

\begin{abstract}
We studied the British and Irish seabird community in the 20th century, a period of great anthropogenic impact. We determined the average body mass of community members and analysed population sizes, phylogenetic and spatial structures. We also quantified the total predation exerted by seabirds around Britain and Ireland and the spatial distribution of this predation in the North Sea. To achieve these aims we used (1) presence or absence of the seabird species in the different counties of Britain and Ireland between 1875 to 1900 and 1968 to 1972, (2) seabird breeding censuses of Britain and Ireland from 1969 to 1970, 1985 to 1988 and 1998 to 2002, (3) at-sea abundance and distribution surveys of seabirds in the North Sea from 1980 to 1985 and 1990 to 1995, and (4) a bioenergetics model to estimate energy expenditures for 40 seabird species. Our analyses suggest a marked expansion in the breeding range of seabirds in Britain and Ireland between 1875 and 1972. Total seabird numbers also increased at an average rate of 1\% per annum between 1969 and 2002, with a related increase of $115 \%$ in predicted total seabird predation. Only terns Sternidae declined during this second period. Some characteristics of the community (geographical and phylogenetic structure, body mass) showed minor and non-significant variability between 1969 and 2002. Finally, seabird predation in the North Sea showed a slight north-eastward shift between 1980 to 1985 and 1990 to 1995. Overall, our study indicates that the seabird community of Britain and Ireland has prospered during the 20th century. These results contrast with extensive breeding failures recorded during the first years of the 21st century, which indicate that certain species within the community are now being critically disturbed.
\end{abstract}

KEY WORDS: Bird phylogeny - Population census - Bioenergetics - Predation - Regime shift · Spatial analysis $\cdot$ Marine environment Resale or republication not permitted without written consent of the publisher

\section{INTRODUCTION}

Disturbance is defined as 'any relatively discrete event in time that disrupts an ecosystem, a community, or the structure of a population and changes resource pools, substrate availability, or the physical environment' (White \& Pickett 1985). Such disturbance may have natural or anthropogenic origins (Turner et al. 2003) and is one of the dominant forces that shape the structure of biological systems (e.g. Wootton 1998). 
Conversely, resilience is defined as the capacity of these systems to face natural or man-made environmental change (and their positive or negative impact) without degrading or shifting to alternate states (Holling 1973, Hughes et al. 2005).

After centuries of use of marine resources by humans, there is now compelling evidence that marine ecosystems are critically disturbed by pollution (Thompson et al. 1992), overfishing (Jackson et al. 2001) and climate change (Pinnegar et al. 2002, Frederiksen et al. 2004). Seabirds also suffer from the impact of human activities, and they are the most threatened bird group (Butchart et al. 2004). Numerous studies have assessed the impact of global climate change and consequences of overfishing on seabird populations (e.g. Croxall et al. 2002, Barbraud \& Weimerskirch 2003). However, to our best knowledge, no study has so far examined the effects of disturbances at the community level. This is an important handicap in management terms, since responses to disturbance can vary substantially across species, taxonomic groups and trophic levels (Wootton 1998).

In the present study, we examined the seabird community of Britain and Ireland, which currently comprises about 8 million birds belonging to 25 different breeding species (Mitchell et al. 2004); these live in some of the most perturbed marine habitats on the planet (Halpern et al. 2008). We defined this 'community' in a taxonomic and functional sense, i.e. a group of species belonging to specific bird families sharing a wide range of life-history traits.

This seabird community has been affected by 4 main factors: (1) fisheries, (2) exploitation for food, (3) species invasions and habitat destruction, and (4) climate change.

(1) The seas around Britain and Ireland have been influenced by industrial fishing since the 19th century (Pauly \& Maclean 2003), with overfishing of many stocks taking place throughout the 20th century as a result of improved fishing technology (e.g. Pauly et al. 1998, Hutchinson et al. 2003, Barrett et al. 2004). Fisheries initially removed large predatory fish such as Atlantic cod Gadus morhua from the system, which were potentially competing with seabirds for resources. Subsequently, mid-trophic forage fish such as Norway pout Trisopterus esmarkii and sandeels Ammodytes spp., which are important seabird prey, were intensively fished and used for fish oil or fishmeal in the agriculture and aquaculture industries (Jennings \& Kaiser 1998). Intensification of industrial fishing also generated vast amounts of discards and offal, a potentially important food source for some seabird species (Garthe et al. 1996, Furness 2003). Fishery activities may, therefore, have positively (removal of competitors, higher availability of fishery refuses) or negatively (removal of seabird live prey, lethal interactions with fishing gear) impacted seabird populations, and it seems likely that the overall balance has fluctuated from positive to negative through time (Tasker et al. 2000).

(2) Enhanced adult mortality and poor breeding performance was initially caused by hunting and egg collection at breeding sites (Ratcliffe 2004).

(3) Breeding seabirds have also been facing alien species of animals and plants, as well as habitat destruction, which can critically affect their breeding performance (Blackburn 2004).

(4) Finally, a seabird community may be structured by global disturbances impacting its environment and often causing changes in prey availability (e.g. Clarke et al. 2003). The regime shift observed in the North Atlantic and adjacent seas during the mid-1980s (Beaugrand 2004, Alheit et al. 2005, Weijerman et al. 2005) is a good example of this. It is thought that this abrupt shift was the result of higher sea temperatures, which caused a northward latitudinal shift in plankton and fish communities (Beaugrand et al. 2002, Perry et al. 2005). Such modifications might have affected the Britain and Ireland seabird community, which is largely constituted of boreal species at the southern edge of their range (Mitchell et al. 2004).

In this study we used published accounts of the spatial distribution of breeding seabirds around Britain and Ireland in 1875 to 1900 and 1968 to 1972 (Holloway 1996); distribution and abundance data from 3 breeding seabird censuses in Britain and Ireland in 1969 to 1970,1985 to 1988 and 1998 to 2002 (Mitchell et al. 2004); and a bioenergetics model to determine population and distributional trends, as well as body mass trends and overall energy requirements. We also used at-sea distributions of seabirds (extracts from the European Seabirds at Sea database [ESAS] from 1979 to 2002) and a bioenergetics model to explore the spatial distribution of seabird predation on marine resources of the North Sea and surrounding waters (English Channel, Baltic Sea and the zones of contact with the North Atlantic), comparing patterns between the breeding and non-breeding seasons for 1979 to 1985 and 1990 to 1995 (before and after the 1983 to 1988 regime shift; Beaugrand 2004).

The overall aim of our study was to investigate the characteristics of the seabird community from Britain and Ireland during a period of great anthropogenic impact, the 20th century. We hypothesized that if major changes occurred within this community, they affected: (1) the species composition, (2) global population and distribution trends, (3) trophic status, (4) predation pressure of the community upon marine resources, and (5) the spatial distribution of this predation pressure. 


\section{MATERIALS AND METHODS}

Study area. The geographic zones considered are: (1) Britain and Ireland and (2) the North Sea and adjacent waters, i.e. the English Channel, the western Baltic Sea and the zone of contact with the North Atlantic, corresponding to the Zones VIIh, VIIe, VIId, IVc, IVb, IVa and IIIa of the International Council for the Exploration of the Seas (ICES).

Seabird populations of Britain and Ireland between 1875 and 1972. This analysis focused on 25 seabird species (Category 1 in Table 1) using data from Holloway (1996), that details the presence or absence of breeding seabirds by counties and by species of Britain and Ireland in 1875 to 1900 and 1968 to 1972 . We cal- culated changes in numbers of counties occupied between the 2 periods (e.g. positive values correspond to an increase in the number of occupied counties).

Seabird populations of Britain and Ireland between 1969 and 2002. This analysis concerned 22 species of seabirds (Category 2 in Table 1) that breed in Britain and Ireland, and used data from Mitchell et al. (2004), who summarize 3 population censuses: Operation Seafarer (1969 to 1970), Seabird Colony Register (SCR) census (1985 to 1988) and Seabird 2000 (1998 to 2002).

Spatial coverage increased with each subsequent survey, with almost complete coverage in the Seabird 2000 census (in Operation Seafarer, coverage was confined to coastal colonies and a part of inland colonies was recorded in the SCR census; more details in

Table 1. Britain and Ireland seabird community species considered in our study. Categories: 1, Seabird population trends in Britain and Ireland between 1875 and 1972; 2, seabird population trends in Britain and Ireland between 1969 and 2002; 3 and 3', predation exerted by seabirds in the North Sea (3 corresponding to breeding species and 3' to non-breeding species)

\begin{tabular}{|c|c|c|c|c|c|}
\hline Order & Family & Species & Common name & Body mass (g) & Category \\
\hline \multirow[t]{23}{*}{ Charadriiformes } & \multirow[t]{5}{*}{ Alcidae } & Cepphus grylle & Black guillemot & 385 & $1,2,3$ \\
\hline & & Uria aalge & Common guillemot & 836 & $1,2,3$ \\
\hline & & Fratercula acrtica & Atlantic puffin & 415 & $1,2,3$ \\
\hline & & Alca torda & Razorbill & 677 & $1,2,3$ \\
\hline & & Alle alle & Little auk & 155 & $3^{\prime}$ \\
\hline & \multirow[t]{9}{*}{ Laridae } & Larus argentatus & Herring gull & 988 & $1,2,3$ \\
\hline & & Larus fuscus & Lesser black-backed gull & 814 & $1,2,3$ \\
\hline & & Larus canus & Mew gull & 410 & $1,2,3$ \\
\hline & & Larus melanocephalus & Mediterranean gull & 796 & 2 \\
\hline & & Larus marinus & Great black-backed gull & 1622 & $1,2,3$ \\
\hline & & Larus ridibundus & Black-headed gull & 265 & $1,2,3$ \\
\hline & & Rissa tridactyla & Black-legged kittiwake & 393 & $1,2,3$ \\
\hline & & Larus minutus & Little gull & 120 & 3 \\
\hline & & Larus hyperboreus & Glaucous gull & 1326 & $3^{\prime}$ \\
\hline & \multirow{4}{*}{ Stercorariidae } & Catharacta skua & Great skua & 1431 & $1,2,3$ \\
\hline & & Stercorarius longicaudus & Long-tailed skua & 350 & 3 \\
\hline & & Stercorarius pomarinus & Pomarine skua & 725 & $3^{\prime}$ \\
\hline & & Stercorarius parasiticus & Arctic skua & 465 & $1,2,3$ \\
\hline & \multirow[t]{5}{*}{ Sternidae } & Sterna paradisaea & Arctic tern & 102 & $1,2,3$ \\
\hline & & Sterna sandvicensis & Sandwich tern & 249 & $1,2,3$ \\
\hline & & Sterna dougallii & Roseate tern & 115 & 1,2 \\
\hline & & Sterna hirundo & Common tern & 125 & $1,2,3$ \\
\hline & & Sterna albifrons & Little tern & 49 & 1,2 \\
\hline \multirow[t]{3}{*}{ Pelecaniformes } & \multirow[t]{2}{*}{ Phalacrocoracidae } & Phalacrocorax carbo & Great cormorant & 2300 & $1,2,3$ \\
\hline & & Phalacrocorax aristotelis & European shag & 1763 & $1,2,3$ \\
\hline & Sulidae & Morus bassanus & Northern gannet & 3015 & $1,2,3$ \\
\hline \multirow[t]{7}{*}{ Procellariiformes } & \multirow[t]{2}{*}{ Hydrobatidae } & Oceanodroma leucorhoa & Leach's storm-petrel & 44 & 1,3 \\
\hline & & Hydrobates pelagicus & European storm-petrel & 25 & 1,3 \\
\hline & \multirow[t]{5}{*}{ Procellariidae } & Fulmarus glacialis & Northern fulmar & 758 & $1,2,3$ \\
\hline & & Calonectris diomedea & Cory's shearwater & 750 & $3^{\prime}$ \\
\hline & & Puffinus puffinus & Manx shearwater & 419 & 1,3 \\
\hline & & Puffinus gravis & Great shearwater & 850 & $3^{\prime}$ \\
\hline & & Puffinus griseus & Sooty shearwater & 819 & $3^{\prime}$ \\
\hline \multirow[t]{3}{*}{ Gaviiformes } & \multirow[t]{3}{*}{ Gaviidae } & Gavia arctica & Black-throated diver & 3000 & $3^{\prime}$ \\
\hline & & Gavia immer & Great Northern diver & 3950 & $3^{\prime}$ \\
\hline & & Gavia stellata & Red-throated diver & 1625 & $3^{\prime}$ \\
\hline \multirow[t]{3}{*}{ Podicipediformes } & \multirow[t]{3}{*}{ Podicipedidae } & Podiceps auritus & Slavonian grebe & 412 & $3^{\prime}$ \\
\hline & & Podiceps cristatus & Great Crested grebe & 975 & $3^{\prime}$ \\
\hline & & Podiceps grisegena & Red-necked grebe & 800 & $3^{\prime}$ \\
\hline Anseriformes & Anatidae & Somateria mollissima & Common eider & 1600 & $1,3^{\prime}$ \\
\hline
\end{tabular}


Mitchell et al. 2004). The quality of the data also improved with time through the development of improved methods (e.g. Seabird 2000 was the first survey to use tape-playback methods and consequently achieved much more accurate estimates of shearwaters and petrels).

Since we were primarily interested in global trends, we used total numbers for each species (sum of all individuals at all breeding sites) and we calculated species-specific population growth rates between the different censuses. For each census period, we also calculated the average body mass of all seabirds within the community $\left(\mathrm{BM}_{\mathrm{ac}} ; \mathrm{g}\right)$ :

$$
\mathrm{BM}_{\mathrm{ac}}=\sum \frac{\mathrm{BM}_{i} \times \text { Numbers }_{i}}{\text { Numbers }_{\text {community }}}
$$

where $\mathrm{BM}_{i}$ is the body mass of each species $i$ in grams (Cramp 1992, Wilson et al. 2004), Numbers ${ }_{i}$ is the number of individuals for each species $i$ and Numbers $_{\text {community }}$ is the total size of the community.

Seabird predation around Britain and Ireland. We used the bioenergetics approach detailed in Tasker \& Furness (1996), and Grémillet et al. (2003) to estimate the yearly food requirements of 40 seabird species for time periods 1969 to 1970,1985 to 1988 and 1998 to 2002. These species are listed in Table 1 (Category 3).

Population size was calculated by adding total numbers of breeding birds, extracted from Mitchell et al. (2004) and estimates of numbers of juveniles and of adult non-breeders. The proportion of juveniles was calculated after Cairns et al. (1991), and the proportion of adult non-breeders after Barrett et al. (2006). Species-specific energy requirements of adults and chicks were taken from the literature when available, or estimated using allometric equations detailed in Ellis \& Gabrielsen (2002). Field metabolic rates (FMR) were used to estimate energy requirements $(E R ; k J$ $\mathrm{d}^{-1}$ ) of seabirds during the breeding season (those of adults $E_{\text {adult, }}$ plus those of the chick) and during the

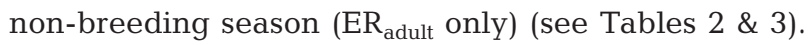
The average number of chicks per nest was taken from the database of the British Trust for Ornithology (available at www.bto.org). Body masses (BM; g) were extracted from Cramp (1992) and Wilson et al. (2004). A fixed energy density of prey of $5.5 \mathrm{~kJ} \mathrm{~g}^{-1}$ wet mass was assumed (see Barrett et al. 2006). The assimilation efficiency (\%) was set to $75 \%$ for adults (ICES 2000) and to $80 \%$ for chicks (Ellis \& Gabrielsen 2002), except when specific information was available for the species considered (Ellis \& Gabrielsen 2002).

Seabird predation in the North Sea. We followed the same bioenergetics approach as above, but instead of calculating the predation using total population numbers, we investigated the spatial distribution of seabird predation in the North Sea. Energy require- ments were calculated as previously (see 'Seabird predation around Britain and Ireland'). We used data from the ESAS database (from 1979 to 2002), covering $3235434 \mathrm{~km}^{2}$ of the North Sea and including 310000 seabird sightings. In the $3235434 \mathrm{~km}^{2}$ sampled, 37 different species were observed (Table 1). These observations were compiled using a spatial resolution of $15^{\prime}$ latitude $\times 30^{\prime}$ longitude for 2 time periods: 1979 to 1985 and 1990 to 1995, which were split into 2 phases: (1) the breeding season (April to June) and (2) the non-breeding season (October to February); 36 species were considered (Table 1). Species with $<100$ individuals for each time period and season were excluded from the analysis. Since sampling effort was not uniform in space and time we used bootstrapping methods to resample all data and reduce this bias. Bootstrapping is often used as an alternative to inference based on parametric assumptions when those assumptions are in doubt, or where parametric inference is impossible or requires very complicated formulas for the calculation of standard errors (Efron \& Tibshirani 1993). Seabird predation was then calculated per square kilometer of the entire study area for each time period and season by multiplying the estimated abundance of each seabird species by its food requirements and adding these total requirements for all species present (ICES 2000). Firstly, we estimated daily food intake (DFI):

$$
\mathrm{DFI}_{i}=\frac{\mathrm{ER}_{i}}{\mathrm{FED}_{\text {prey }}} \times \frac{1}{0.75}
$$

where $\mathrm{DFI}_{i}$ is the daily food intake for each species $i$ ( $\mathrm{kg}$ of food), $\mathrm{ER}_{i}$ is the energy requirements for each

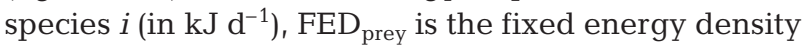
of prey of $5.5 \mathrm{~kJ} \mathrm{~g}^{-1}$ wet mass and $0.75(75 \%$ is the mean assimilation efficiency for each species $i$ ).

Total food consumption per square kilometer was then estimated as:

$$
\mathrm{PP}_{\mathrm{km} 2}=\sum\left(\mathrm{FI}_{\text {iseason }} \times \mathrm{AD}_{i}\right)
$$

where $\mathrm{PP}_{\mathrm{km} 2}$ is the predation per square kilometer $(\mathrm{kg}$ of food), $\mathrm{FI}_{i \text { season }}$ is the food intake for each species $i$ according to the target season ( $\mathrm{kg}$ of food), and $\mathrm{AD}_{i}$ is the adjusted density of each species $i$ (density per $\mathrm{km}^{2}$ sampled; seabird density at sea is adjusted by using various correction factors to account for, e.g., detectability of different species at various distances from the survey platform; details in Stone et al. 1995). Predation per square kilometer was calculated separately for each season (the breeding season lasts for $91 \mathrm{~d}$ and the non-breeding season for $151 \mathrm{~d}$ ) and each time period. Data were projected into a standard background map of the North Sea provided by ICES (www.ices.dk, accessed 31 July 2007) with the planar projection GSC WGS 1984 using ArcView 8.2. 
Statistical analyses. We considered 3 factors according to their ecological importance (e.g. Nagy et al. 1999): taxonomic status (i.e. family), ecological niche (i.e. diet; Cramp 1992) and average body mass of each species. To standardise these 3 factors in qualitative data, we used body mass classes for all species. According to Sturges' rule (Sturges 1926), we divided the community into 5 classes of very small (0 to $603 \mathrm{~g}$ ), small (604 to $1206 \mathrm{~g}$ ), intermediate (1207 to $1809 \mathrm{~g}$ ), large (1810 to $2412 \mathrm{~g}$ ) and very large species (2313 to $3015 \mathrm{~g}$ ). We used Dixon's test to detect outlier species on a whole-species basis (Gibbons 1994). Two-factor ANOVA or general linear models (i.e. GLM) were used to test for these factors (i.e. family, diet and body mass class) and periods (i.e. 1875 to 1900 and 1968 to 1972) on occupied county numbers of breeding seabirds and proportional species composition (i.e. seabird numbers of each species divided by total seabird numbers). Student's $t$-tests were used to examine change in seabird numbers between the different censuses according to the same 3 ecological factors. Kruskal-Wallis tests allowed us to perfect these analyses, and Wilcoxon $U$ tests, to compare the average body mass of community members at the different periods. We also employed a standardised principal component analysis (PCA) and a cluster analysis to detect spatial and temporal trends in the seabird community using data from Mitchell et al. (2004). The standardised PCA was applied on a table of 108 observations ( 36 counties $\times 3$ time periods) and 14 variables (14 species). Prior to the analysis, abundance data for each county and species $\left(x_{i}\right)$ were normalised so that the sum of the square of the time periods was equal to 1 . The transformation $y_{i}$ was done as follows:

$$
y_{i}=\frac{x_{i}}{\sqrt{\sum_{i=1}^{n} x_{i}^{2}}}
$$

$y_{i}$ is the transformed abundance data for time period $i_{\text {, }}$ $x_{i}$ the original abundance data for time period $i$, and $n$ the number of time periods $(n=3)$. This normalisation procedure was used to give the same weight to each species and county (Beaugrand \& Ibañez 2004). Such transformation is commonly applied in 3-mode PCA (Beaugrand et al. 2000).

Eigenvectors were normalised as follows:

$$
\mathbf{U}_{\mathbf{n}}=\mathbf{U} \Lambda^{\frac{1}{2}}
$$

$\mathbf{U}_{\mathbf{n}}$ being the matrix of normalised eigenvectors, $\mathbf{U}$ being the matrix of eigenvectors and $\Lambda$ being the diagonal matrix of eigenvalues. Thus, the variables in the space of eigenvectors represented the linear correlation with the first and the second principal component (Legendre \& Legendre 1998). This allowed us to add a circle of correlation of 1 . When variables are close to this circle, they contribute significantly to the space. The circle of equilibrium descriptor contribution $C$ (Legendre \& Legendre 1998) was also represented to see which variables contribute most strongly to the reduced space. $C$ was calculated as follows:

$$
C=\sqrt{\frac{d}{p}}
$$

$d$ is the number of dimensions, and $p$ is the number of variables used in the analysis. $d$ was equal to 2 in the PCA, $p=14$ species and therefore $C=0.38$. All variables inside the circle are not correctly represented in this space.

A cluster analysis based upon Ward's procedure (i.e. minimization of intra-class variance) was employed to further investigate spatial structure. Regions showing homogeneous variation over time were identified and combined to represent county clusters based on species composition. This cluster analysis was applied for each time period over the period 1969 to 1970 and 1985 to 1988 , we did not take inland zones into account because they were not, or only partially, surveyed (Mitchell et al. 2004).

Analyses were conducted using Minitab and Matlab, with an accepted p-level at 0.05.

\section{RESULTS}

\section{Seabird populations of Britain and Ireland between 1875 and 1972}

Between 1875 and 1972 no seabird species was lost and there was an overall expansion in breeding range of the seabird population of Britain and Ireland, with the number of counties occupied increasing from 31 to $47\left(F_{1,48}=5.43, \mathrm{p}=0.024\right)$. This geographical expansion likely stems from population growth. For instance, northern gannets Morus bassanus markedly extended both their breeding range (10 counties occupied in 1900 and 19 in 1969 to 1970) and total population size (49000 breeding pairs in 1900 and 187908 from 1984 to 1988) during this period. Changes in species range expansion were also significantly influenced by taxonomy $\left(F_{8,41}=6.06, \mathrm{p}<0.001\right)$, but not by body mass $\left(F_{5,45}=1.61, \mathrm{p}=0.189\right)$. Out of 9 studied families, only the Sternidae and Laridae occupied significantly more counties in 1972 than in $1875\left(t_{5}=6.80, \mathrm{p}=0.002\right.$ and $t_{6}=7.48, \mathrm{p}=0.001$, respectively; Fig. 1). Piscivorous species occupied more counties in later periods $\left(t_{13}=\right.$ $3.60, \mathrm{p}=0.004$ ), as well as the smallest species (class of body mass 0 to $603 g_{i} t_{14}=3.68, \mathrm{p}=0.002$ ), and the largest species (classes of body mass 1207 to $3015 \mathrm{~g}$; $t_{6}=2.98, \mathrm{p}=0.031 ;$ Table 1 ) . 


\section{Seabird populations of Britain and Ireland between 1969 and 2002}

Between 1969 and 2002 there was no species loss and proportional species composition remained unchanged $\left(F_{2,56}<0.001, \mathrm{p}=1.000 ;\right.$ e.g. European shag featured $1.2 \%$ of the overall populations in 1969 to $1970,3.3 \%$ in 1985 to 1988 and $1.7 \%$ in 1998 to 2002). Our analysis revealed a significant effect of seabird body mass classes on community composition $\left(H_{4}=\right.$ 23.32, p < 0.001). The body mass class 604 to $1206 \mathrm{~g}$ was the most numerous in recent times; for example, it corresponded to approximately $60 \%$ of total numbers between 1998 and 2002. Piscivorous species were also numerous $(65.75 \%$ in 1969 to $1970,74.3 \%$ in 1985 to 1988 and $75 \%$ in 1998 to 2002).

Seabird breeding populations increased by $34 \%$ (4 780000 to 6396000 ind.) between 1969 and 2002, representing an augmentation of approximately $1 \% \mathrm{yr}^{-1}$. The initial growth rate was $25 \%$ between 1969 and 1988, subsequently decreasing to $7 \%$ between 1985 and 2002 . This rate was not influenced by body mass classes $\left(F_{4,52}\right.$ $=0.54, p=0.704$ ), with the exception of species weighing between 1207 and $3015 \mathrm{~g}$. The 9 species contained in this class declined by $12.7 \%$ between 1969 to 1970 and 1985 to $1988\left(t_{5}=7.18, \mathrm{p}=0.002\right)$. Taxonomic status had a significant impact on population trends $\left(F_{6,43}=3.88, \mathrm{p}=\right.$ $0.003)$. The Sternidae declined significantly $\left(t_{5}=-7.43\right.$, $p=0.002)$. In 1969 , tern numbers corresponded to $3.6 \%$ of total community numbers, against $2.2 \%$ in 2002 . Laridae numbers also decreased between 1969 and 1988 $\left(t_{5}=-4.40, \mathrm{p}=0.012\right)$, but stabilized between 1988 and 2002, with a similar growth rate to the whole community $\left(t_{5}=1.09, \mathrm{p}=0.336\right)$. Piscivorous species had a higher population growth rate than other species between 1969 and $1988\left(t_{11}=-3.98, \mathrm{p}=0.003\right)$, but not between 1988 and $2002\left(t_{11}=-1.68, \mathrm{p}=0.124\right)$.

The average body mass of community members showed no significant change during the study period $\left(U_{22}=115.0, \mathrm{p}=0.721\right)$. Nevertheless, it increased slightly from $804 \mathrm{~g}$ in 1969 to $860 \mathrm{~g}$ in 2002.

\section{Spatial analyses of seabird population trends between 1969 and 2002}

Long-term spatial changes were examined for 14 species using a standardised PCA. Values of the first principal component increased with time for nearly all counties taken into consideration in the analysis (Fig. 2). Species that were positively correlated with the first component exhibited an increase in abundance between 1969 to 1970 and 1985 to 1988 , the time of the North Sea regime shift. Timing of the regime shift in the North Sea is between 1982 and 1988 according to species (Beaugrand 2004). Herring gull

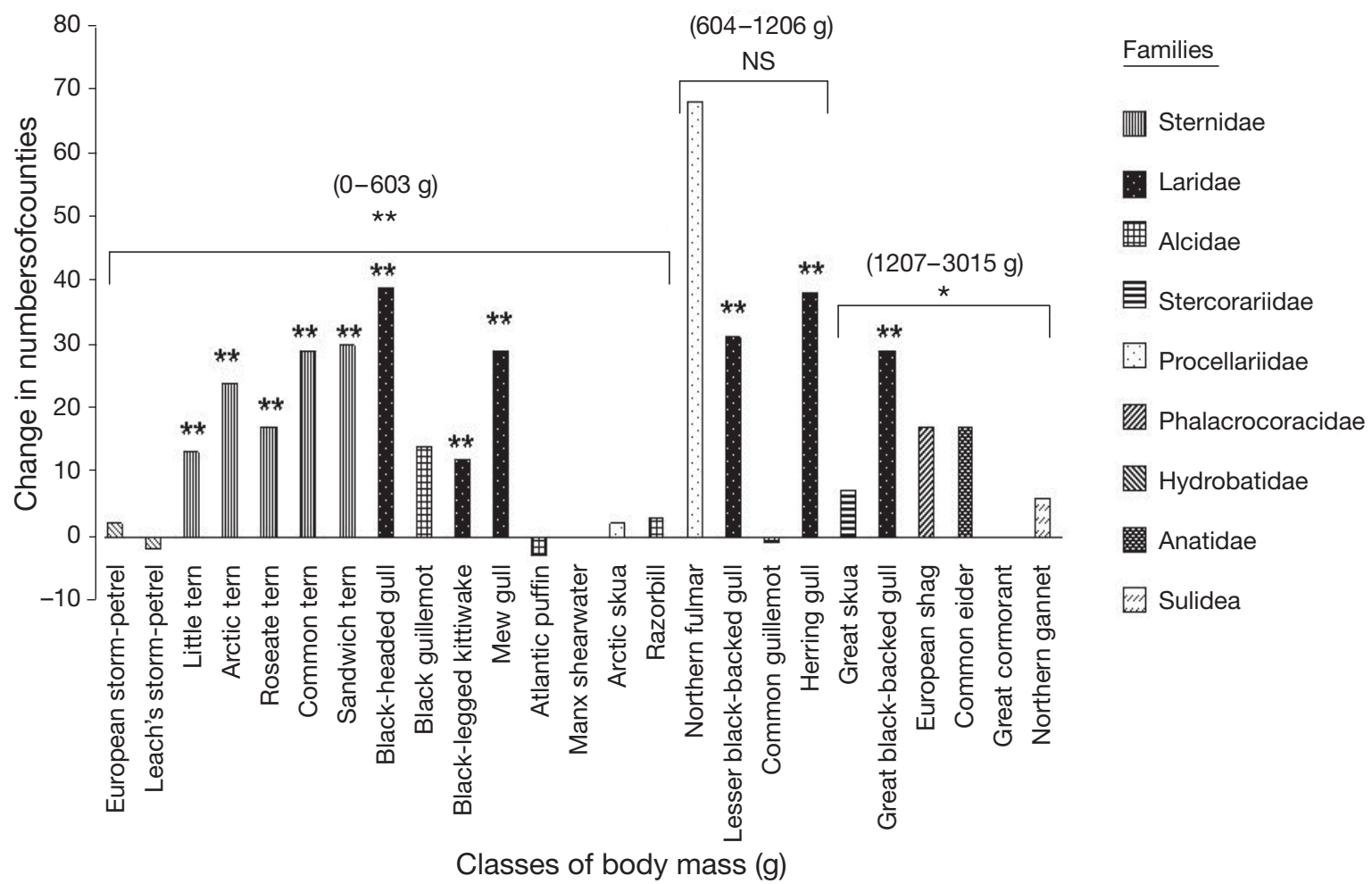

Fig. 1. Change in the number of counties of Britain and Ireland occupied by seabirds in 1875 and in 1972 according to their taxonomic status and their body mass $(\mathrm{g})$. NS: non-significant difference between the 2 time periods; ${ }^{*} \mathrm{p}<0.05 ;{ }^{* *} \mathrm{p}<0.025$ 
Fig. 2. Standardised PCA for 108 observations (counties and periods) $\times 14$ species. (a) Normalised Eigenvectors 1 and $2(35.57 \%$ of the total variance); both circle of correlation (outer circle) and circle of equilibrium (inner circle) descriptor contribution $(C=0.38)$ are displayed. The latter circle allows an examination of the contribution of each descriptor in the reduced space. A variable inside this circle has a non-significant contribution. (b) Long-term changes in the first principal component. (c) Long-term changes in the second principal component. Numbers are counties and the 3 levels of grey indicate the 3 time periods considered in the analysis. Counties were coded as follows: $(1,37,73$ for time periods 1,2 and 3 , respectively) Shetland; $(2,38,74)$ Orkney; $(3,39,75)$ Caithness; $(4,40,76)$ Sutherland; $(5,41,77)$ Ross \& Cromarty; $(6,42,78)$ Banff \& Buchan $;(7,43$, 79) Gordon $;(8,44,80)$ Kincardine \& Deeside; $(9,45,81)$ Northeast Fife; $(10,46,82)$ East Lothian; $(11,47,83)$ Stewartry; $(12,48,84)$ Wigtown $(13$, $49,85)$ Kyle \& Carrick; $(14,50,86)$ Argyll \& Bute; $(15,51,87)$ Lochaber; $(16$, $52,88)$ Skye \& Lochalsh; $(17,53,89)$ Western Isles Comhairle nan eilean; $(18,54,90)$ Northumberland; $(19,55,91)$ Dorset; $(20,56,92)$ Channel Islands; $(21,57,93)$ Cornwall; $(22,58,94)$ Isles of Scilly; $(23,59,95)$ Devon; $(24,60,96)$ Cumbria; $(25,61,97)$ Isle of Man; $(26,62,98)$ Dyfed $_{i}(27,63,99)$ Gwynedd; $(28,64,100)$ Co. Antrim $;(29,65,101)$ Co. Down $(30,66,102)$ Co. Dublin; $(31,67,103)$ Co. Wexford; $(32,68,104)$ Co. Cork $;(33,69,105)$ Co. Kerry; $(34,70,106)$ Co. Galway; $(35,71,107)$ Co. Mayo; $(36,72,108)$ Co. Donegal
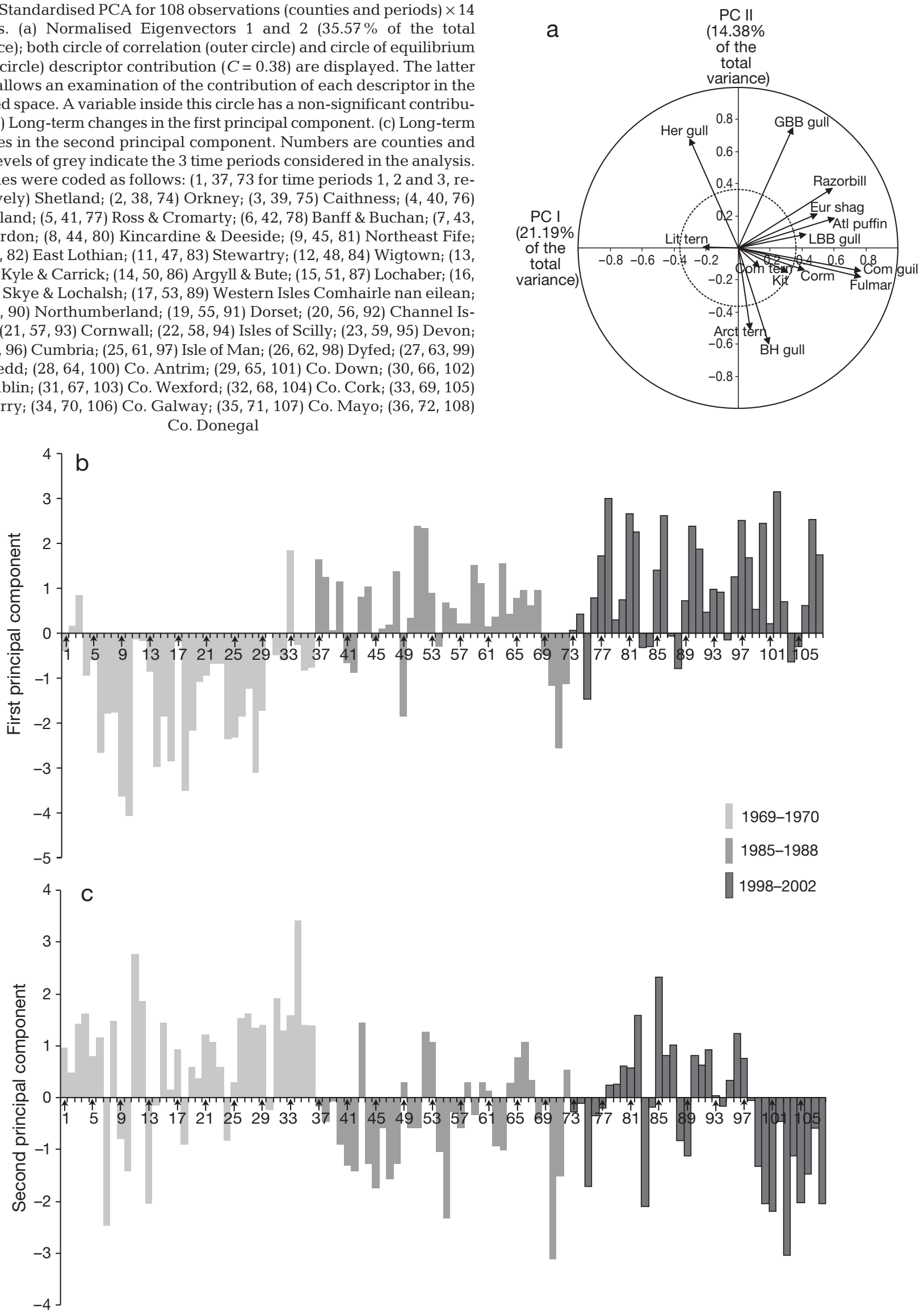
Fig. 3. Standardised PCA for 108 observations (counties and periods) $\times 14$ species. (a) Normalised eigenvectors 1 and 3 (33.91\% of the total variance); both circle of correlation (outer circle) and circle of equilibrium (inner circle) descriptor contribution $(C=0.38)$ are displayed. The latter circle allows an examination of the contribution of each descriptor in the reduced space. A variable inside this circle has a non-significant contribution. (b) Long-term changes in the third principal component. Numbers are counties and the 3 levels of grey indicate the 3 time periods considered in the analysis. Counties were coded as in Fig. 2

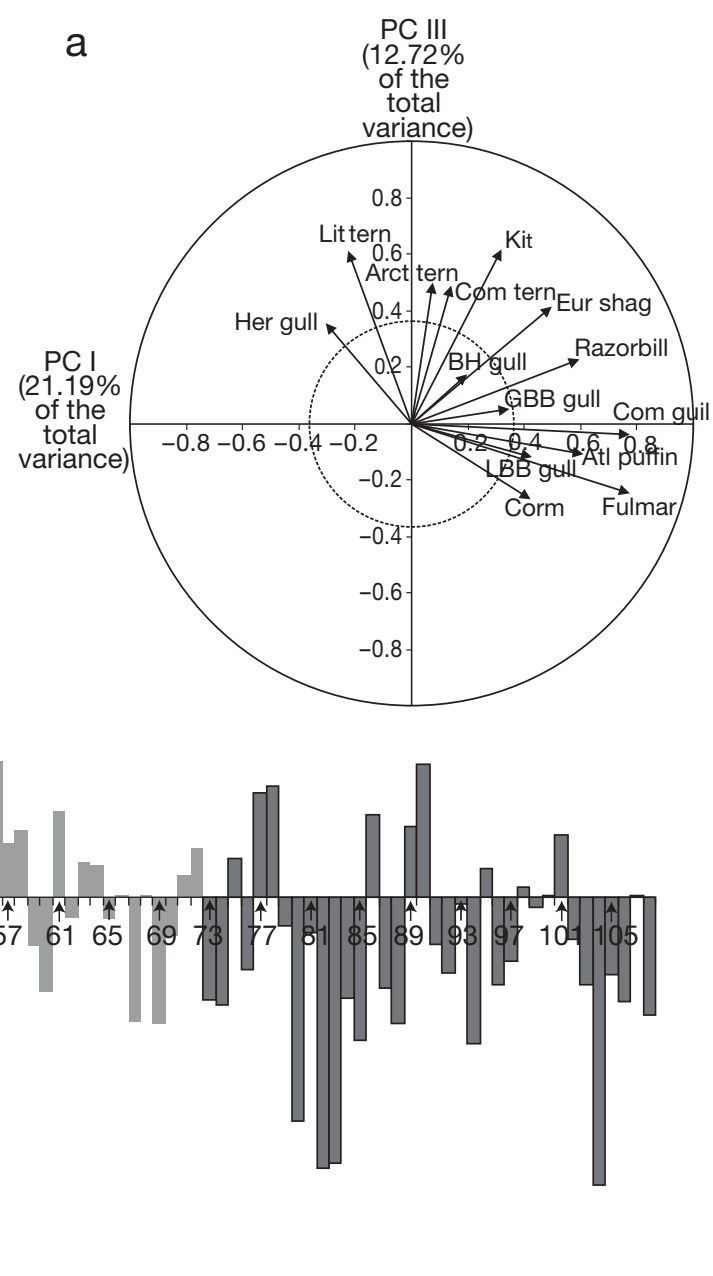

Larus argentatus and great black-backed gull Larus marinus showed a decrease in abundance between 1969 to 1970 and 1985 to 1988, which reversed in some counties between 1998 and 2002 (Fig. 2). All terns, and black-legged kittiwakes Rissa tridactyla, showed a decrease in abundance after the period from 1985 to 1988 in the majority of the counties (Fig. 3).

For the remaining seabird species within the community, the PCA did not reveal significant changes for the 1962 to 2002 time period, except in Shetland. In this region there was a decrease in the size of colonies for all species except black-headed gull after the period from 1985 to 1988 (Figs. 2 \& 3). Long-term changes in the Shetland colonies are distinct but not opposite from other regions as demonstrated by the first 3 principal components. Similar changes, but not as pronounced as in Shetland, were also observed in a few locations across Britain (Sutherland, Kincardine \& Deeside, Wigtown, Lochaber, Gwynedd).

Finally, our cluster analysis revealed spatial structuring of the community with 4 independent zones, but with very little variability across the study period. A northern cluster gathering Shetland, Orkney and the
Western Isles-Comhairle nan eilean (Fig. 4, purple), was clearly isolated from the rest. A second cluster (Fig. 4, green), representing primarily Sternidae, the black-headed gull and the lesser black-backed gull, expanded northwards during 1985 to 1988, but subsequently retreated. The third cluster (Fig. 4, yellow) mainly contained northern gannets and black-legged kittiwakes, and tended to decrease its distributional range during the study period. Finally, a last area corresponding to inland populations could only be displayed for the 1998 to 2002 period, and showed no specific core area (Fig. 4, blue).

\section{Seabird predation around Britain and Ireland}

The seabird community of Britain and Ireland weighed a total of $40380 \mathrm{t}$ in 1969 to $1970,58910 \mathrm{t}$ in 1985 to 1988 and $71200 \mathrm{t}$ in 1998 to 2000. We estimated that it consumed $378500 \mathrm{t}$ of food $\mathrm{yr}^{-1}$ in 1969 to 1970 , $577200 \mathrm{t} \mathrm{yr}^{-1}$ in 1985 to 1988 and $813200 \mathrm{t} \mathrm{yr}^{-1}$ in 1999 to 2002 . Seabird predation around Britain and Ireland has therefore increased by $115 \%$ since the 1970 s. 


\section{Seabird predation in the North Sea}

Our calculations indicate that northern gannets have the highest daily food requirements of all North Sea seabirds (1360 $\mathrm{g} \mathrm{d}^{-1}$ in summer and $1179 \mathrm{~g} \mathrm{~d}^{-1}$ in winter), followed by great cormorants (1337 $\mathrm{g} \mathrm{d}^{-1}$ in summer and $801 \mathrm{~g} \mathrm{~d}^{-1}$ in winter). These values accord well with previous estimates provided by Grémillet et al. (2000) and Enstipp et al. (2006). Conversely, Sandwich terns and Leach's storm-petrels are predicted to have the lowest food requirements (32 and $35 \mathrm{~g} \mathrm{~d}^{-1}$ in summer and 16 and $29 \mathrm{~g} \mathrm{~d}^{-1}$ in winter, respectively). Note that summer food requirements are higher because of the additional energy demand of the brood (Tables $2 \& 3$ ).

During the summers of 1979 to 1985 , predation was highest in the western North Sea, more specifically, along the east coast of Scotland, around Orkney, Shetland, and in the northern North Sea. Summer predation increased markedly during the 1990 to 1995 time period, with a north-eastward shift in predation pressure (Fig. 5a). During the winter period from 1979 to 1985, predation was most intense in the central western North Sea, off the east coast of England and Scotland, and south of Shetland. The pattern generally remained during the 1990 to 1995 period, although there was also a shift in predatory pressure towards the eastern North Sea (Fig. 5b). These eastward shifts during the winter and summer periods 1990 to 1995 compared to 1979 to 1985 might be partly due to more extensive seabird monitoring in the eastern North Sea and the Baltic Sea.

\section{DISCUSSION}

Our results indicate that the seabird community of Britain and Ireland has prospered in the 20th century. This contrasts with the fate of the global avifauna (Owens 2000, Pimm et al. 2006), land bird communities from tropical and sub-tropical areas (Sekercioglu et al. 2002, Sodhi et al. 2004), the European land bird community (Julliard et al. 2004) and the worldwide seabird community, within which the petrels have been massively affected by incidental catches on fishing lines (BirdLife International 2001).

Some caution is nevertheless required in interpreting our findings. The databases used are outstanding sources of information but remain incomplete. For instance, population data (Mitchell et al. 2004) were not recorded for some zones and species during Operation Seafarer and the SCR census. In addition, although we included a spatial dimension to our analysis, the lack of real time series might have blurred any potential impact of the 1980s regime shift on the seabird community (Beaugrand 2004). Furthermore, sampling of seabird abundance and distribution in the North Sea was not standardised, i.e. some zones and/or time periods were more intensively monitored than others. We did, however, use a bootstrapping resampling technique to reduce this spatiotemporal bias. Data randomisation tempered the fact that: (1) estimates of population numbers obtained at sea were not temporally and spatially uniform (Camphuysen et
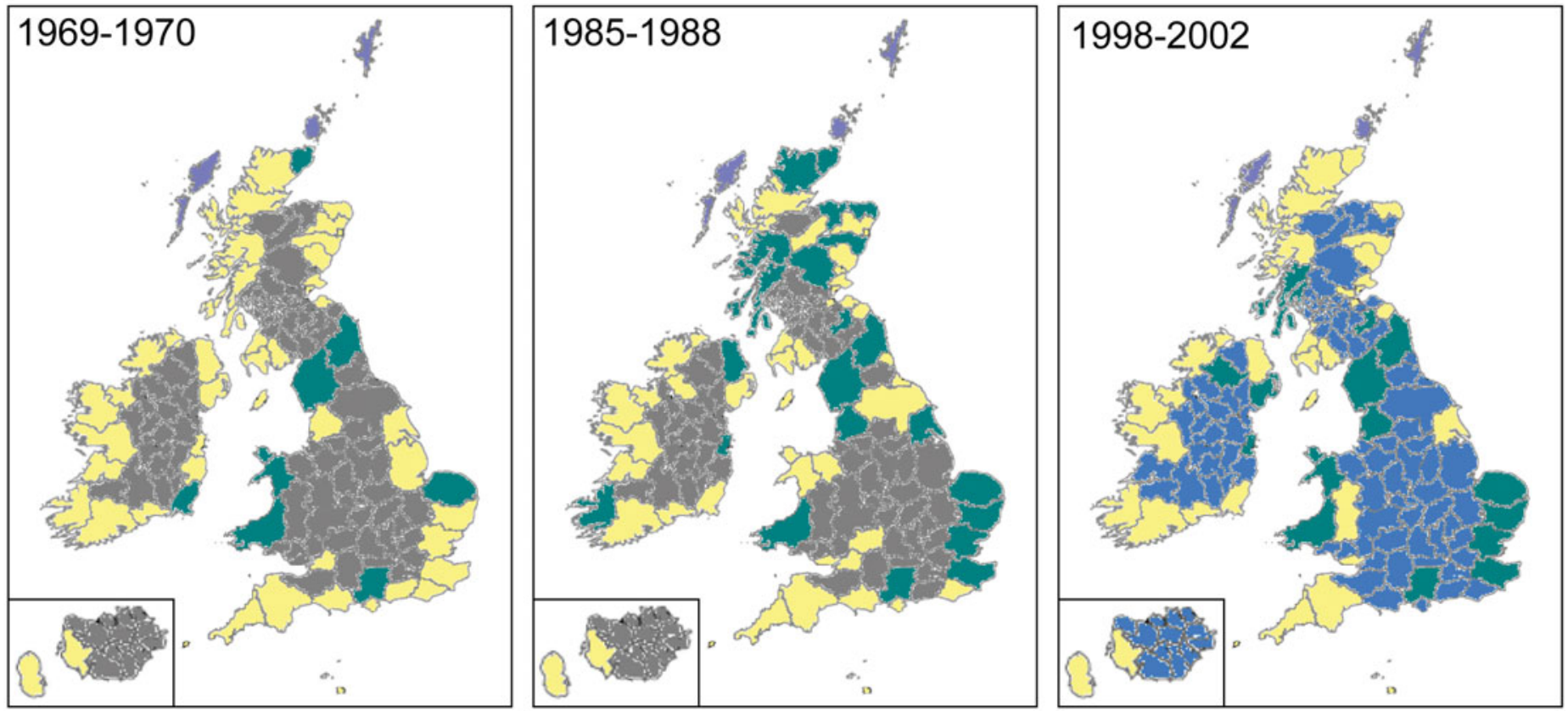

Fig. 4. Cluster analyses of seabird breeding distribution in Britain and Ireland in 1969 to 1970, 1985 to 1988 and 1998 to 2002 allowed the distinction of 4 different zones (marked in purple, green, yellow and blue; see 'Results' for details). Grey zones show areas for which no data were recorded. Inset: Glasgow detail 
Table 2. Daily food intake (DFI) of the breeding seabird species considered in our study, according to their field metabolic rates (FMR) or allometric equation for species or species groups (Ellis \& Gabrielsen 2002). m: body mass in grams (allometric equation)

\begin{tabular}{|c|c|c|c|}
\hline \multirow[t]{2}{*}{ Breeding species } & \multirow{2}{*}{$\begin{array}{l}\text { FMR }\left(\mathrm{kJ} \mathrm{h}^{-1} \mathrm{~g}^{-1}\right) \\
\text { or allometric } \\
\text { equation }\left(\mathrm{kJ} \mathrm{d}^{-1}\right)\end{array}$} & \multicolumn{2}{|c|}{ DFI $\left(\mathrm{g} \mathrm{d}^{-1}\right)$} \\
\hline & & Summer & Winter \\
\hline Arctic skua & $11.49 m^{0.718}$ & 269.26 & 229.15 \\
\hline Arctic tern & 0.127 & 83.45 & 75.37 \\
\hline Atlantic puffin & 0.0768 & 192.25 & 178.30 \\
\hline Black guillemot & 0.0942 & 242.48 & 211.01 \\
\hline Black-backed gull & $11.49 m^{0.718}$ & 599.67 & 457.50 \\
\hline Black-headed gull & $11.49 m^{0.718}$ & 186.80 & 153.03 \\
\hline Common / Arctic tern & $11.49 m^{0.718}$ & 96.61 & 83.25 \\
\hline Common / Herring gull & $11.49 m^{0.718}$ & 383.81 & 307.07 \\
\hline Common guillemot / Razorbill & $11.49 m^{0.718}$ & 334.30 & 325.00 \\
\hline Mew gull & $11.49 m^{0.718}$ & 262.64 & 209.35 \\
\hline Common tern & 0.1125 & 96.78 & 81.82 \\
\hline Great cormorant & $3.90 m^{0.871}$ & 1093.15 & 719.19 \\
\hline European shag & $3.90 m^{0.871}$ & 893.50 & 595.80 \\
\hline European storm-petrel & $22.06 m^{0.594}$ & 40.82 & 36.19 \\
\hline Great black-backed gull & $11.49 m^{0.718}$ & 746.51 & 561.97 \\
\hline Great cormorant & $3.90 m^{0.871}$ & 1337.39 & 801.13 \\
\hline Great skua & $11.49 m^{0.718}$ & 590.52 & 472.66 \\
\hline Guillemot & 0.0893 & 426.11 & 417.65 \\
\hline Herring / Lesser black-backed gull & $11 \quad 11.49 m^{0.718}$ & 393.87 & 368.46 \\
\hline Herring gull & $11.49 m^{0.718}$ & 480.93 & 371.39 \\
\hline Black-legged kittiwake & 0.0848 & 237.30 & 191.35 \\
\hline Leach's storm-petrel & 0.114 & 35.18 & 29.18 \\
\hline Lesser black-backed gull & $11.49 m^{0.718}$ & 437.45 & 342.55 \\
\hline Little gull & $11.49 m^{0.718}$ & 99.29 & 86.65 \\
\hline Manx shearwater & $22.06 m^{0.594}$ & 230.17 & 193.10 \\
\hline Northern fulmar & 0.0826 & 373.43 & 329.17 \\
\hline Northern gannet & 0.0672 & 1359.87 & 1178.81 \\
\hline Razorbill & $11.49 m^{0.718}$ & 298.39 & 288.55 \\
\hline Sandwich tern & $11.49 m^{0.718}$ & 166.59 & 144.73 \\
\hline Small gull ${ }^{\mathrm{a}}$ & $11.49 m^{0.718}$ & 48.29 & 16.21 \\
\hline Tern & $11.49 m^{0.718}$ & 120.96 & 105.90 \\
\hline Unidentified gull & $11.49 m^{0.718}$ & 417.08 & 337.09 \\
\hline Unidentified large gull & $11.49 m^{0.718}$ & 559.15 & 428.96 \\
\hline Unidentified storm-petrel & $11.49 m^{0.718}$ & 50.36 & 43.82 \\
\hline
\end{tabular}

Despite such limitations, important conclusions emerge from our analyses. Unlike in many perturbed ecosystems, no species has disappeared from the seabird community of Britain and Ireland during the 20th century, and, generally speaking, abundance has been increasing. Moreover, the phylogenic and geographic structure of the community has remained fairly stable during the study period (no species loss, no major change in geographic structure), despite a slight increase in average body mass potentially suggesting an impoverishment of trophic width typical of strongly perturbed marine food webs (Pauly et al. 1998).

Despite a marked disturbance, the seabird community of Britain and Ireland on the whole has prospered during the 20th century. We propose 3 potential, mutually non-exclusive explanations for this community growth.

Firstly, it is highly likely to have featured a recovery period after centuries of persecution: seabirds were extensively hunted, but protection measures since the end of the 19th century (1869 'Protection of Birds at Sea' Act) have meant that their exploitation has now largely diminished. Initially, legislation proved most beneficial for the Laridae and Sternidae. This could be explained by the fact that these 2 groups usually breed at sites which are accessible and are consequently more open to persecution than other seabird species (Lloyd et al. 1991). As seabirds are long-lived animals with a low reproductive rate, the majority of their populations only started to show signs of recovery after several decades, with growth being

al. 1995) and (2) estimates were inaccurate because when data on at-sea seabird distribution and abundance were collected, specific areas were surveyed and these were not chosen randomly (Van der Meer \& Camphuysen 1996). Finally, although both the structure and the input values of our bioenergetics models were as realistic as possible, we must stress that all calculations presented here are theoretical.

Further investigations are therefore required, and, in particular, continued, accurate long-term monitoring of seabird numbers, investigations of seabird at-sea distribution and abundance, and refined knowledge of seabird foraging behaviour and energetics, especially for species $<1000 \mathrm{~g}$, which dominate the community, but have been far less studied than larger species. most apparent during the second half of the 20th century. Over the last $15 \mathrm{yr}$ population growth rates have declined, suggesting that some species, such as northern gannets and black-legged kittiwakes, are now being regulated via density-dependent effects (Frederiksen et al. 2005, Wanless et al. 2005).

Secondly, the impact of human fisheries appears to have been mostly beneficial to the seabird community of Britain and Ireland, mainly by removing potential seabird competitors from the system (large predatory fish) and/or by producing vast amounts of additional seabird food via fishery refuses (see 'Introduction'). For instance, seabird species weighing $>1200 \mathrm{~g}$ declined between 1969 and 1988, but became constant afterwards. This stabilization and consequent range expan- 
sion (Lloyd et al. 1991) may have been due to increased levels of fishery discard, food which is predominantly gathered by large species such as great skua, great blackbacked gull and northern gannet (Garthe \& Hüppop 1994, Votier et al. 2004).

Finally, climate change and the accompanying ecosystem shift, which affected the entire North Atlantic during the 1980s, significantly raised ocean temperatures in the North Sea (Beaugrand 2004), and may have created more favourable environmental conditions for some seabird species (Thompson 2006).

Overall, our study shows that the seabird community of Britain and Ireland has been remarkably resilient to environmental change in the 20th century. However, the relative importance of protection measures at breeding sites, positive and negative impacts of industrial fisheries and climate change remain unclear and deserve further analysis.

The apparent growth of the seabird community of Britain and Ireland in the 20th century contrasts strongly with some regional and species-specific patterns during this period. For example, seabird breeding numbers in Shetland, in particular for terns and black-legged kittiwakes, showed dramatic declines from the late 1980s, and remain in comparatively low numbers (Suddaby \& Ratcliffe 1997, Heubeck et al. 1999, Frederiksen et al. 2005, Harris et al. 2006). Reasons for these trends remain unclear, although they might be linked to a fishery-induced and/or climate-driven regional population crash of the lesser sandeel Ammodytes marinus, an essential prey item for the local marine avifauna (Arnott \& Ruxton 2002).

Since 2004, spectacular breeding failures of formerly abundant species, such as the black-legged kittiwake, have not only been recorded in Shetland, but also all along the east coast of Britain (Mavor et al. 2005, 2006, Wanless et al. 2005). The current hypothesis states that these declines are linked to low availability and low energy content of lesser sandeels. This may have resulted from a trophic cascade driven by warmer water temperatures in the eastern Atlantic (Beaugrand et al. 2000, Wanless et al. 2007).

Fig. 5. Percentage change in: (a) summer and (b) winter seabird predation between the 1979 to 1985 and 1990 to 1995 time periods
Table 3. Daily food intake (DFI) of non-breeding seabird species considered in our study, according to their field metabolic rate (FMR), estimated by an allometric equation (Ellis \& Gabrielsen 2002). m: body mass in grams

\begin{tabular}{|lccc|}
\hline \multirow{2}{*}{$\begin{array}{l}\text { Non breeding species } \\
\text { in the zone }\end{array}$} & Allometric & \multicolumn{2}{c|}{ DFI $\left(\mathrm{g} \mathrm{d}^{-1}\right)$} \\
& equation $\left(\mathrm{kJ} \mathrm{d}^{-1}\right)$ & Summer & Winter \\
\hline Black-throated diver & $16.69 \mathrm{~m}^{0.651}$ & 742.40 & 742.40 \\
Common eider & $16.69 \mathrm{~m}^{0.651}$ & 493.08 & 493.08 \\
Cory's shearwater & $22.06 \mathrm{~m}^{0.594}$ & 272.88 & 272.88 \\
Glaucous gull & $11.49 \mathrm{~m}^{0.718}$ & 486.28 & 486.28 \\
Great Crested grebe & $16.69 \mathrm{~m}^{0.651}$ & 357.17 & 357.17 \\
Great Northern diver & $16.69 \mathrm{~m}^{0.651}$ & 888.01 & 888.01 \\
Great shearwater & $22.06 m^{0.594}$ & 293.94 & 293.94 \\
Great / Cory's shearwater & $22.06 m^{0.594}$ & 283.54 & 283.54 \\
Little auk & $11.49 m^{0.718}$ & 104.12 & 104.12 \\
Long-tailed skua & $11.49 m^{0.718}$ & 186.87 & 186.87 \\
Pomarine skua & $11.49 m^{0.718}$ & 315.22 & 315.22 \\
Red-necked grebe & $16.69 m^{0.651}$ & 314.01 & 314.01 \\
Red-throated diver & $16.69 m^{0.651}$ & 498.08 & 498.08 \\
Slavonian grebe & $16.69 m^{0.651}$ & 204.02 & 204.02 \\
Sooty shearwater & $22.06 m^{0.594}$ & 287.52 & 287.52 \\
Unidentified auk & $11.49 m^{0.718}$ & 239.33 & 239.33 \\
Unidentified diver & $16.69 m^{0.651}$ & 719.50 & 719.50 \\
\hline
\end{tabular}
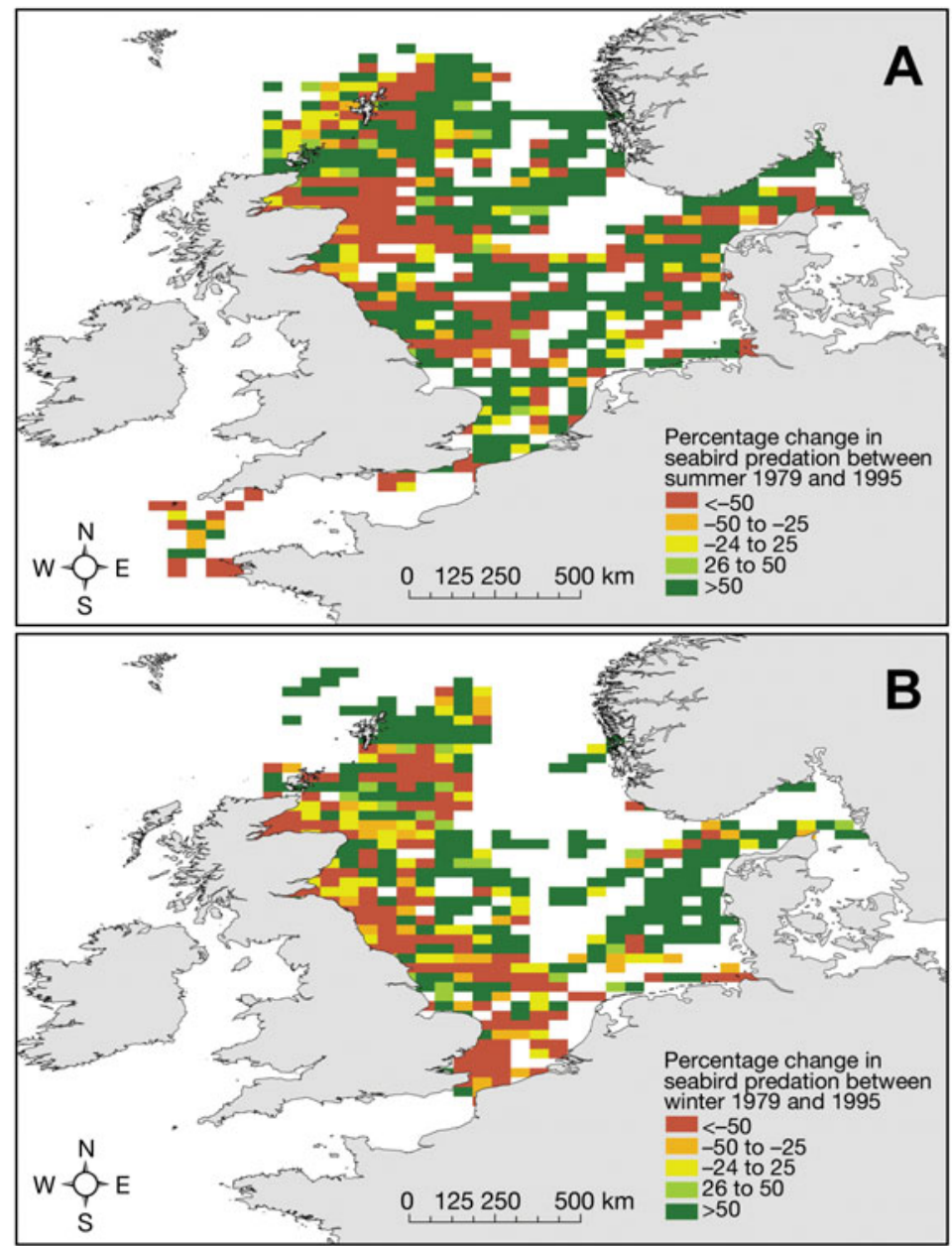
Acknowledgements. We thank the many people who gathered seabird data around Britain and Ireland, and in the North Sea, in particular, ESAS data providers from Instituut voor Bos- en Natuuronderzoek, The Netherlands, Instituut voor Natuur- en Bosonderzoek, Belgium, Joint Nature Conservation Committee, National Environmental Research Insitute Kalo, Norsk Institutt for Naturforskning; Ornis Consult, University College Cork and Vogelwarte Helgoland.

\section{LITERATURE CITED}

Alheit J, Möllmann C, Dutz J, Kornilovs G, Loewe P, Mohrholz V, Wasmund N (2005) Synchronous ecological regime shifts in the central Baltic and the North Sea in the late 1980s. ICES J Mar Sci 62:1205-1215

Arnott SA, Ruxton GD (2002) Sandeel recruitment in the North Sea: demographic, climatic and trophic effects. Mar Ecol Prog Ser 238:199-210

Barbraud C, Weimerskirch H (2003) Climate and density shape population dynamics of a marine top predator. Proc R Soc Lond B Biol Sci 270:2111-2116

Barrett JH, Locker AM, Roberts MR (2004) The origins of intensive marine fishing in medieval Europe: the English evidence. Proc R Soc Lond B Biol Sci 271:2417-2421

Barrett RT, Chapdelaine G, Anker-Nilsson T, Mosbech A, Montevecchi WA, Reid J, Veit RR (2006) Seabird numbers and prey consumption in the North Atlantic. ICES J Mar Sci 63:1145-1158

Beaugrand G (2004) The North Sea regime shift: evidence, mechanisms and consequences. Prog Oceanogr 60:245-262

> Beaugrand G, Ibañez F (2004) Monitoring marine plankton ecosystems. II. Long-term changes in North Sea calanoid copepods in relation to hydro-climatic variability. Mar Ecol Prog Ser 284:35-47

Beaugrand GF, Ibañez PC, Reid PC (2000) Spatial, seasonal and long-term fluctuations of plankton in relation to hydroclimatic features in the English Channel, Celtic Sea and Bay of Biscay. Mar Ecol Prog Ser 200:93-102

Beaugrand G, Reid PC, Ibañez F, Lindley JA, Edwards M (2002) Reorganisation of North Atlantic marine copepod biodiversity and climate. Science 296:1692-1694

BirdLife International (2001) Threatened birds of the world. Available at http://www.birdlife.org

Blackburn TM (2004) Avian extinction and mammalian introductions on oceanic islands. Science 305:1955

Butchart SHM, Stattersfield AJ, Bennun LA, Shutes SM, Akçakaya HR, Baillie JEM, Stuart SN (2004) Measuring global trends in the status of biodiversity: red list indices for birds. PLoS Biol 2(12):e383

Cairns DK, Chapdelaine G, Montevecchi WA (1991) Prey exploitation by seabirds in the Gulf of St. Lawrence. In: Therriault JC (eds) The Gulf of St. Lawrence: Small ocean or big estuary? Canadian Special Publication of Fisheries and Aquatic Sciences, Mont-Joli, p 277-291

Camphuysen CJ, Calvo B, Durinck J, Ensor K and others (1995) Consumption of discards by seabirds in the North Sea. Final Report EC DG XIV Research Contract BIOECO/93/10, NIOZ-Rep, Netherlands Institute for Sea Research, Texel

Clarke ED, Spear LB, McCracken ML, Marques FF, Borchers DL, Buckland ST, Ainley DG (2003) Validating the use of generalized additive models \& at-sea surveys to estimate size and temporal trends of seabird populations. J Appl Ecol 40:278-292

Cramp S (1992) The birds of the western Palearctic, Vol VI: Warblers. In: Cramp S (eds) Handbook of the birds of
Europe, the Middle East and North Africa. Oxford University Press, Oxford

Croxall JP, Trathan PN, Murphy EJ (2002) Environmental change and Antarctic seabird populations. Science 297: 1510-1514

Efron B, Tibshirani RJ (1993) An introduction to the bootstrap. Monographs on statistics and applied probability, No. 57. Chapman \& Hall, London

Ellis HI, Gabrielsen GW (2002) Energetics of free-ranging seabirds. In: Schreiber EA, Burger J (eds) Biology of marine birds CRC Press, Boca Raton, p 357-405

Enstipp MR, Daunt F, Wanless S, Humphreys EM, Hamer KC, Benvenuti S, Grémillet D (2006) Foraging energetics of North Sea birds confronted with fluctuating prey availability. In: Boyd IL, Wanless S, Camphuysen CJ (eds) Top predators in marine ecosystems. Symposium of the Zoological Society London. Cambridge University Press, Cambridge, p 191-210

Frederiksen M, Wanless S, Rothery P, Wilson LJ (2004) The role of industrial fisheries and oceanographic change in the decline of North Sea black-legged kittiwakes. J Appl Ecol 41:1129-1139

> Frederiksen M, Wright PJ, Heubeck M, Harris MP, Mavor RA, Wanless S (2005) Regional patterns of kittiwake Rissa tridactyla breeding success are related to variability in sandeel recruitment. Mar Ecol Prog Ser 300:201-211

Furness RW (2003) Impacts of fisheries on seabirds communities. Mediterranean seabirds and their conservation. Sci Mar 67:33-45

Garthe S, Hüppop O (1994) Distribution of ship-following seabirds and their utilization of discards in the North Sea in summer. Mar Ecol Prog Ser 106:1-9

Garthe S, Camphuysen CJ, Furness RW (1996) Amounts of discards by commercial fisheries and their significance as food for seabirds in the North Sea. Mar Ecol Prog Ser 136:1-11

Gibbons RD (1994) Statistical methods for groundwater monitoring. John Wiley \& Sons, New York

> Grémillet D, Storch S, Peters G (2000) Determining food requirements in marine top-predators: a comparison of three independent methods in great cormorants Phalacrocorax carbo. Can J Zool 78:1567-1579

Grémillet D, Wright G, Lauder A, Carss DN, Wanless S (2003) Modelling the daily food requirements of wintering great cormorants: a bioenergetics tool for wildlife management. J Appl Ecol 40:266-277

Halpern BS, Walbridge S, Selkoe KA, Kappel CV and others (2008) A global map of human impact on marine ecosystems. Science 319:948-949

Harris MP, Heubeck M, Shaw DN, Okill JD (2006) Dramatic changes in the return date of common guillemots to colonies in Shetland, 1962-2005. Bird Study 53:247-252

Heubeck M, Mellor RM, Harvey PV, Mainwood AR, Riddington $R$ (1999) Estimating the population size and rate of decline of kittiwake breeding in Shetland, 1981-97. Bird Study 46:48-61

> Holling CS (1973) Resilience and stability of ecological systems. Annu Rev Ecol Syst 4:1-23

Holloway S (1996) The historical atlas of breeding birds in Britain and Ireland 1875-1900. Black Publishers, London

> Hughes TP, Bellwood DR, Folke C, Steneck RS, Wilson J (2005) New paradigms for supporting the resilience of marine ecosystems. Trends Ecol Evol 20:380-386

> Hutchinson WF, van Oosterhout C, Rogers SI, Carvalho GR (2003) Temporal analysis of archived samples indicates marked genetic changes in declining North Sea cod (Gadus morhua). Proc R Soc Lond B Biol Sci 270: 
$2125-2132$

ICES (International Council for the Exploration of the Sea) (2000) Report of the working group on seabird ecology. Doc. CM, 04, ICES, Aberdeen

Jackson RB, Carpenter SR, Dahm CN, McKnight DM, Naiman RJ, Postel SL, Running SW (2001) Water in a changing world. Ecol Appl 11:1027-1045

Jennings S, Kaiser MJ (1998) The effects of fishing on marine ecosystems. Adv Mar Biol 34:201-352

Julliard R, Jiguet F, Couvet D (2004) Common birds facing global changes: What makes a species at risk? Glob Change Biol 10:148-154

Legendre P, Legendre L (1998) Numerical ecology, 2nd edn. Elsevier Science BV, Amsterdam

Lloyd CS, Tasker ML, Partridge K (1991) The status of seabirds in Britain and Ireland. Black Publishers, London

Mavor RA, Parsons M, Heubeck M, Schmitt S (2005) Seabird numbers and breeding success in Britain and Ireland, 2004. Joint Nature Conservation Committee, Peterborough

Mavor RA, Parsons M, Heubeck M, Schmitt S (2006) Seabird numbers and breeding success in Britain and Ireland, 2005. Joint Nature Conservation Committee, Peterborough

Mitchell PI, Newton SF, Ratcliffe N, Dunn TE (2004) Seabird populations of Britain and Ireland. Results of the Seabird 2000 census (1998-2002). Black Publishers, London

Nagy KA, Girard IA, Brown TK (1999) Energetics of freeranging mammals, reptiles and birds. Annu Rev Nutr 19: 247-277

Owens IPF (2000) Ecological basis of extinction risk in birds: habitat loss versus human persecution and introduced predators. Proc Natl Acad Sci USA 97:12144-12148

Pauly D, Maclean J (2003) A perfect ocean. In: A perfect ocean: fisheries and ecosystem in the North Atlantic. Island Press, Washington, DC

Pauly D, Christensen V, Dalsgaard J, Froese R, Francisco T Jr (1998) Fishing down marine food webs. Science 279: 860-863

Perry AL, Low PJ, Ellis JR, Reynolds JD (2005) Climate change and distribution shifts in marine fishes. Science 308:1912-1915

Pimm S, Raven P, Peterson A, Sekercioglu CH, Ehrlich PR (2006) Human impacts on the rates of recent, present, and future bird extinctions. Proc Natl Acad Sci USA 103: 10941-10946

Pinnegar JK, Jennings S, O'Brien CM, Polunin NVC (2002) Long-term changes in the trophic level of the Celtic Sea fish community and fish market price distribution. J Appl Ecol 39:377-390

Ratcliffe N (2004) Causes of seabird population change. In: Poyser T, Poyser AD (eds) Seabird populations of Britain and Ireland. Black Publishers, London, p 407-441

Sekercioglu CH, Ehrlich PR, Daily GC, Aygen D, Goehring D, Sandí R (2002) Disappearance of insectivorous birds from tropical forest fragments. Proc Natl Acad Sci USA 99: 263-267

Editorial responsibility: Peter Corkeron,

Woods Hole, Massachusetts, USA
Sodhi NS, Liow LH, Bazzaz FA (2004) Avian extinctions from tropical and subtropical forests. Annu Rev Ecol Evol Syst 35:323-345

Stone CJ, Webb A, Barton C, Ratcliffe N and others (1995) An atlas of seabird distribution in north-west European waters. Joint Nature Conservation Committee, Peterborough

Sturges HA (1926) The choice of a class interval. J Am Stat Assoc 21:65-66

Suddaby D, Ratcliffe N (1997) The effects of fluctuating food availability on breeding Arctic terns. Auk 114:524-570

Tasker M, Furness RW (1996) Estimation of food consumption by seabirds in the North Sea. ICES Coop Res Rep 216: $6-42$

- Tasker ML, Camphuysen CJ, Cooper J, Garthe S, Montevecchi WA, Blaber SJM (2000) The impacts of fishing on marine birds. ICES J Mar Sci 57:531-547

Thompson PM (2006) Identifying drivers of change; Did fisheries play a role in the spread of North Atlantic fulmars? In: Boyd IA, Wanless S, Camphuysen CJ (eds) Management of marine ecosystems: monitoring change in upper trophic levels. Cambridge University Press, Cambridge

> Thompson DR, Furness RW, Walsh PM (1992) Historical changes in mercury concentrations in the marine ecosystem of the North and North East Atlantic Ocean as indicated by seabird feathers. J Appl Ecol 29:79-84

Turner MG, Collins SL, Magnuson JJ, Scott Rupp T, Swanson FJ (2003) Disturbance dynamics and ecological response: the contribution of long term ecological research. Bioscience 53:46-56

Van der Meer J, Camphuysen CJ (1996) Effect of observer differences on abundance estimates of seabirds from shipbased strip transect surveys. Ibis 138:433-437

Votier SC, Furness RW, Bearhop S, Crane JE and others (2004) Changes in fisheries discard rates and seabird communities. Nature 427:727-730

Wanless S, Harris MP, Redman P, Speakman JR (2005) Low energy values of fish as a probable cause of a major seabird breeding failure in the North Sea. Mar Ecol Prog Ser 294:1-8

Wanless S, Frederiksen M, Daunt F, Scott BE, Harris MP (2007) Black-legged kittiwakes as indicators of environmental change in the North Sea: evidence from long-term studies. Prog Oceanogr 72:30-38

Weijerman M, Lindeboom H, Zuur AF (2005) Regime shifts in marine ecosystems on the North Sea and Wadden Sea. Mar Ecol Prog Ser 298:21-39

White PS, Pickett STA (1985) Natural disturbance and patch dynamics: an introduction. In: Pickett STA, White PS (eds) The ecology of natural disturbance and patch dynamics. Academic Press, New York, p 3-13

Wilson LJ, Bacon PJ, Bull J, Dragosits U and others (2004) Modelling the spatial distribution of ammonia emissions from seabirds in the UK. Env Polit 131:173-185

> Wootton JT (1998) Effects of disturbance on species diversity: a multitrophic perspective. Am Nat 152:803-825

Submitted: August 21, 2007; Accepted: September 9, 2008

Proofs received from author(s): November 30, 2008 